\section{Yellow rain}

\section{Australian report goes public}

\section{Washington}

FURTHER details of an Australian Government analysis that concluded that alleged "yellow rain" samples were fakes emerged last week as the new Labor Government agreed to release the report of the analysis (see Nature, 17 March, p.200).

The report, dated August 1982, had not been publicly circulated. Speculation has it that this was to avoid embarrassment to the United States, which has repeatedly claimed to have proof that yellow rain is a toxin weapon being used under Soviet supervision in South-East Asia.

The Australian analysis, performed by Dr Hugh Crone of the Department of Defence Support Materials Research Laboratory, concludes that "the samples examined are not toxic and in fact are composed of yellow pollen grains, probably with a small amount of binder"'. The pollen appears in the form of yellow spots adhering to leaves and pebbles, which, the report says, "were deliberately applied, either by a brush or by a spraying process"'. The report explicitly rules out the possibility that the spots are of natural origin.

The pollen in most of the samples matched that of the genus Harpullia, a group of rain forest trees that includes the tulipwood. The report notes that "one tree producing pollen from many flowers at one time would furnish enough material" to produce all the samples received by the Australians. Pollen from other tropical plants (Sterculiaceae, Dilleniaceae, Cupaniaeae, Sapindaceae) and from cereals (Poaceae) and the daisy family (Compositae) were also found in smaller quantities.

According to Phil Harrison of the Australian Embassy in Washington, the samples were turned over to the Australian Embassy in Thailand by a Laotian refugee in mid-April. Harrison said the Australians, who had earlier offered to analyse any material relating to "yellow rain", were informed by the American Embassy that the samples were available.

The report notes that because little systematic study has been made of pollen in South-East Asia, "it has not proved possible to identify grains to a level that could assist in locating the area of origin of the samples within South-East Asia'. The bulk of the pollen, though, is probably derived from rainforest, the report says; the small amount of cereal and weed pollen present in some of the samples "could suggest that samples were taken from secondary forest trees close to cleared agricultural areas"'.

Unlike the US analyses, the Australians' did not specifically analyse for trichothecene mycotoxins, the fungal toxins that the United States maintains are the deliberate - and lethal - component of yellow rain. But the Australians did perform a simple toxicological test (application to shaved rat skin), which the report says is sensitive to $500 \mathrm{ng}$ of DAS or T-2, two of the chief mycotoxins. The results were all negative. "If we accept $500 \mathrm{ng}$ as the upper limit, this cannot represent a militarily-effective residue", the report concludes.

The report also notes the presence of fungi, including Fusaria, on some of the samples. Fusaria are the natural source of mycotoxins.

Meanwhile, until more is known about the pollen that has reportedly been found in many, if not all, of the samples that the United States and other countries collected in Thailand, the only sure conclusion is, as the report states, that "since the [Australian] samples are obviously fakes, they convey no information at all as to the veracity or otherwise of the reports of chemical attacks", Stephen Budiansky

\section{University staffing}

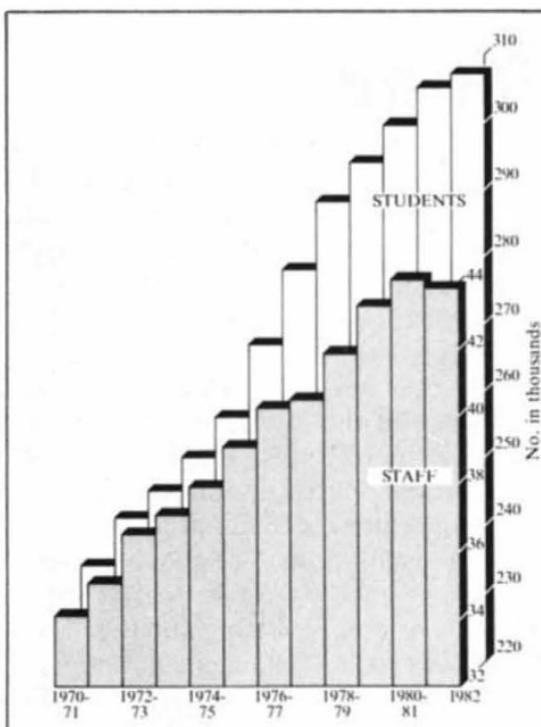

Source: University Statistics 1981-82, Volume I (University Statistical Office, Cheltenham, f7.50).

THE total number of full-time students at university in the United Kingdom, both undergraduate and postgraduate, has risen by 31 per cent since 1970 . This has been matched by a corresponding 29 per cent increase in the number of full-time staff, so that the ratio of students to staff has remained almost constant throughout Great Britain during this period, being 7.6 to 1 in England (standard deviation 0.13) and 7.5 in Wales and Scotland (s.d. 0.12 and 0.28 respectively), and has improved in Northern Ireland, falling from 10.4 in 1971-72 to 8.6 in 1980-81. However, as the number of students continues to rise, albeit at a rather slower rate, and the number of staff begins to fall, the reduction in the staff to student ratio in 1981-82 can only continue. Melanie Kee
Sizewell B inquiry

\section{Opposition}

\section{falters}

ALL is not going according to plan for the Sizewell B Appeal Fund, set up in January to support objectors at the marathon public inquiry now taking place at Snape in Suffolk.

The fund hopes to raise $£ 0.5$ million to finance groups at the inquiry opposing the plans of the Central Electricity Generating Board (CEGB) to spend $£ 1,100$ million on building Britain's first pressurized water reactor (PWR) at Sizewell. But the chairman of the fund's Appeal Committee, $\mathrm{Mr}$ Edward Irving, says that so far the fund "has not attracted the support we have hoped for".

The fund got off to a promising start when seven distinguished trustees were appointed to oversee applications for support within three weeks of the fund's foundation (Nature 10 February, p.457). The National and Local Government Officers Association, which has declared itself in favour of nuclear power, gave $£ 1,000$ to the fund in February, saying that it believed the donation would "assist towards the achievement of a fair and well-informed decision by the inspector". However, no other unions are known to have contributed, and approaches to industrial companies have so far failed to produce much positive response. The Appeal Committee may have to reconsider the fund's future unless more money arrives soon.

At the inquiry itself, CEGB and British Nuclear Fuels Limited have completed their initial presentation of evidence before the Inspector, Sir Frank Layfield QC. Objectors are now getting the first real chance to show their mettle with the crossexamination of Mr R. Priddle, the Department of Energy's only witness. The thrust of Mr Priddle's evidence was that it would be dangerous for the country to rely excessively on coal for its future energy requirements.

During cross-examination from $\mathrm{Mr}$ John Blake, vice-chairman of the Town and Country Planning Association, $\mathrm{Mr}$ Priddle acknowledged that the government had moved away from the 15-GW, 10-year programme of nuclear power station building that was planned in 1979. The number of new nuclear power stations that the government would like to see built in the next decade is now thought to be nearer four or five than the ten originally foreseen. Lower predictions for future electricity demand have inspired the shift: indeed, demand for electricity in the United Kingdom actually fell by 0.1 per cent last year. However, CEGB expects demand for electricity to increase to the end of the century even if total energy demand falls.

The importance of the nuclear power programme is now framed more in terms of its strategic contribution (diversifying 